\title{
Energy and Emission Reduction Potential for Bank ATM Units in India
}

\author{
Hemant Kumar Singh ${ }^{1}$, Ravi Prakash ${ }^{*}$, Karunesh Kumar Shukla² \\ ${ }^{1}$ Department of Mechanical Engineering, Motilal Nehru National Institute of Technology, Allahabad, India \\ ${ }^{2}$ Department of Applied Mechanics, Motilal Nehru National Institute of Technology, Allahabad, India \\ Email: *rprakash234@gmail.com
}

How to cite this paper: Singh, H.K., Prakash, R. and Shukla, K.K. (2016) Energy and Emission Reduction Potential for Bank ATM Units in India. Open Journal of Energy Efficiency, 5, 107-120.

http://dx.doi.org/10.4236/ojee.2016.54010

Received: September 6, 2016

Accepted: November 1, 2016

Published: November 4, 2016

Copyright (c) 2016 by authors and Scientific Research Publishing Inc. This work is licensed under the Creative Commons Attribution International License (CC BY 4.0).

http://creativecommons.org/licenses/by/4.0/

\begin{abstract}
With the growing economy of India, banking sector growth has led to installation of thousands of Automatic Teller Machines (ATMs) throughout the country. ATMs provide $24 \times 7$ services as well as operate at low-temperature ranges of cooling, hence have high operating energy costs. Insulating an ATM's envelope is not a prevalent technique in India. In the present study, an effort has been made to determine the optimum insulation thickness for three different insulation materials for the typical ATM envelope in four different climatic zones of India. Life cycle savings and payback periods for various insulation materials are also evaluated. Further, these optimally insulated ATM envelopes can be integrated with grid connected rooftop solar PV systems. The energy saving and emissions reduction potential due to these two interventions have been estimated on the national basis. Altogether in the four selected climate zones, energy saving of $17 \%$ - $30 \%$ provides the annual economic benefit of Indian National Rupees (Rs.) 3570 million with annual carbon reduction potential of about 0.60 million $\mathrm{tCO}_{2}$. From this study, it is observed that properly insulated ATMs integrated with rooftop solar PV systems, can significantly reduce the energy costs as well as carbon emissions in India's context.
\end{abstract}

\section{Keywords}

Life Cycle Cost, Optimum Insulation Thickness, Life Cycle Saving, Solar PV, Payback Period, Carbon Emissions

\section{Introduction}

Rapid population growth, urbanization and quality of life improvement in India have led to a substantial increase in energy demand outstripping the supply. Energy supply is very capital intensive and therefore energy saving is essential for bridging the supply- 
demand gap. In India, four sectors that have major energy consumption are industry, transportation, building and agriculture. Building construction in India is estimated to grow at a rate of $6.6 \%$ per year in the next two decades [1]. In India, primary electricity consumption in commercial buildings is reported as around $8 \%$ [2] and more than half of this usage is utilized in HVAC. Effective thermal insulation of building envelope holds a significant role in the reduction of heat gain and hence energy consumption for cooling purposes. Buildings should be insulated according to the outdoor environmental conditions and indoor thermal comfort requirements. Al-Homoud [3] presented an overview of the basic principles of thermal insulation, their performance characteristics and proper applications. It surveyed and categorized the most commonly used building insulation materials into three group viz. inorganic materials, organic materials and metallic or metalized reflective membranes. Increasing insulation thickness increases capital investment, but reduces cooling energy cost considerably. However, beyond a certain insulation thickness, the energy reduction cost will not make up for the applied insulation cost [4] and thus there must be a situation where the total expenditure on insulation and energy consumption both can be minimized over the lifespan of the insulation material. Hence, the selection of a suitable insulation material and its optimum thickness is an essential requirement. Life cycle cost (LCC) concept was utilized to optimise the insulation thickness for rock wool \& polystyrene, for two typical wall structures for Israel [5]. Optimum insulation thickness (OIT), net energy cost savings was estimated and energy consumption of residential buildings was forecasted for different degree-day regions of Turkey [6] [7] [8] [9] [10]. Effect of wall orientation and surface colours of building walls on the OIT was studied [11] [12] [13]. For Turkey, application of expanded polystyrene (EPS), insulation at OIT results in life cycle savings (LCS) of $14.09 \$ / \mathrm{m}^{2}$ as well as $41.53 \%$ reduction in $\mathrm{CO}_{2}$ emissions [14] [15]. Insulating walls for cooling applications provide more energy savings than for heating applications in Turkey for polystyrene insulation [16] [17]. Depending on the type of fuel used, variation of OIT from $5.3 \mathrm{~cm}$ to $12.4 \mathrm{~cm}$ was observed in Turkey [18]. Reduce the heat gain and losses in building by applying OIT of thermal insulation as well as inter-relate the OIT of insulation materials for various structure wall and their orientations using an implicit finite-difference method under dynamic thermal conditions for Turkey [19] [20] [21]. In another study, Ozel and Pihtili [22] investigated the optimum location and distribution of insulation and reported that best thermal performance was obtained with one of three equal pieces insulation layers was placed in the outdoor surface of wall, the second piece in the middle and third piece was placed in the indoor surface of wall. Due to energy-efficient measures in China, it was concluded that for heating application, thick insulation assists in reduction of the energy use as well as in carbon footprint [23] [24]. Embodied $\mathrm{CO}_{2}$ emission and impact of different insulation material on the primary energy-use was investigated for a residential apartment building in Sweden [25]. Various locations of insulation layers for building walls were studied with the aim of achieving best overall dynamic performance under OIT [26]. Thermal performance building envelopes in Saudi Arabia was compared and reported that insulation closer to 
the inside surface of the roof and outside to the wall have better effect on the instantaneous heat-transfer load reduction [27] [28]. Khawaja [29] utilized standard solar radiation model to generate solar radiation and calculate sol-air temperature for the city of Doha in Qatar and investigated the optimum insulation thickness taking into account of the impact of the solar energy radiation. On the basis of life cycle energy consumption, OIT of EPS insulation was obtained for residential buildings in India [30] [31]. From the literature, it is evident that for cooling applications, relatively less attention has been paid to address the benefits of building envelope insulation in Indian context.

With the growing economy of India, banking sector growth has led to installation of thousands of Automatic Teller Machines (ATMs) throughout the country. These are used for cash withdrawal, account statement etc. ATMs provide $24 \times 7$ services as well as operate at low temperature ranges of cooling, hence have high operating energy costs. In spite of this, insulating an ATM's envelope is not a prevalent technique in India. In the present study, an effort has been made to determine the optimum insulation thickness for three different insulation materials for the typical ATM envelope in four different climatic zones of India. Life cycle savings and payback periods for various insulation materials are also evaluated. Further, these optimally insulated ATM envelopes can be integrated with grid connected rooftop solar PV (SPV) systems. The energy saving and emissions reduction potential due to these two interventions have been estimated on the national basis. Further, an attempt has been made to generate a database for architects/construction industry practitioners to select the most attractive system depending upon the climatic zone. The study also helps the government for policy making for energy conservation measures applied to building sector.

\section{Methodology}

The methodology opted to determine the most appropriate insulation material and its thickness for maximum energy saving as well as maximum economic benefits is demonstrated in Figure 1.

\subsection{Structural Composition with Insulation}

India is divided into five major climatic zones: hot \& dry, composite, warm \& humid, moderate, and cold (Figure 2). Minimum eight months of cooling is required for hot $\&$ dry, composite, and warm \& humid climates. Moderate regions require around five to six months of cooling, while no cooling is required for the cold region. Cooling appliances for providing thermal comfort absorb heat transmitted to the cooling space through the building envelope, and these tend to have high electricity consumption. A survey was conducted to explore the building materials commonly used for ATM buildings. Figure 3 show the typical cross section of the external wall and roof. It was observed that the wall structure comprises fired clay bricks (FCB) with cement plaster on both sides and roof structure comprises reinforced cement concrete (RCC) sandwiched between cement plaster on both sides, with no insulation material in-between. Table 1 presents the physical and thermal characteristics of the ATM envelope and its constituents. 


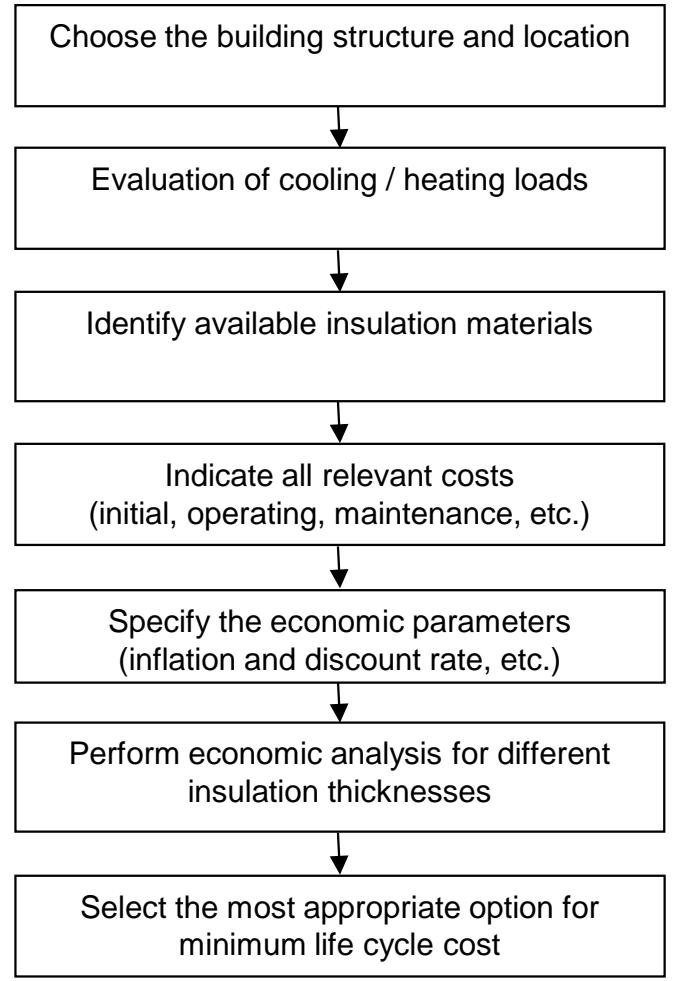

Figure 1. Methodology flow diagram.

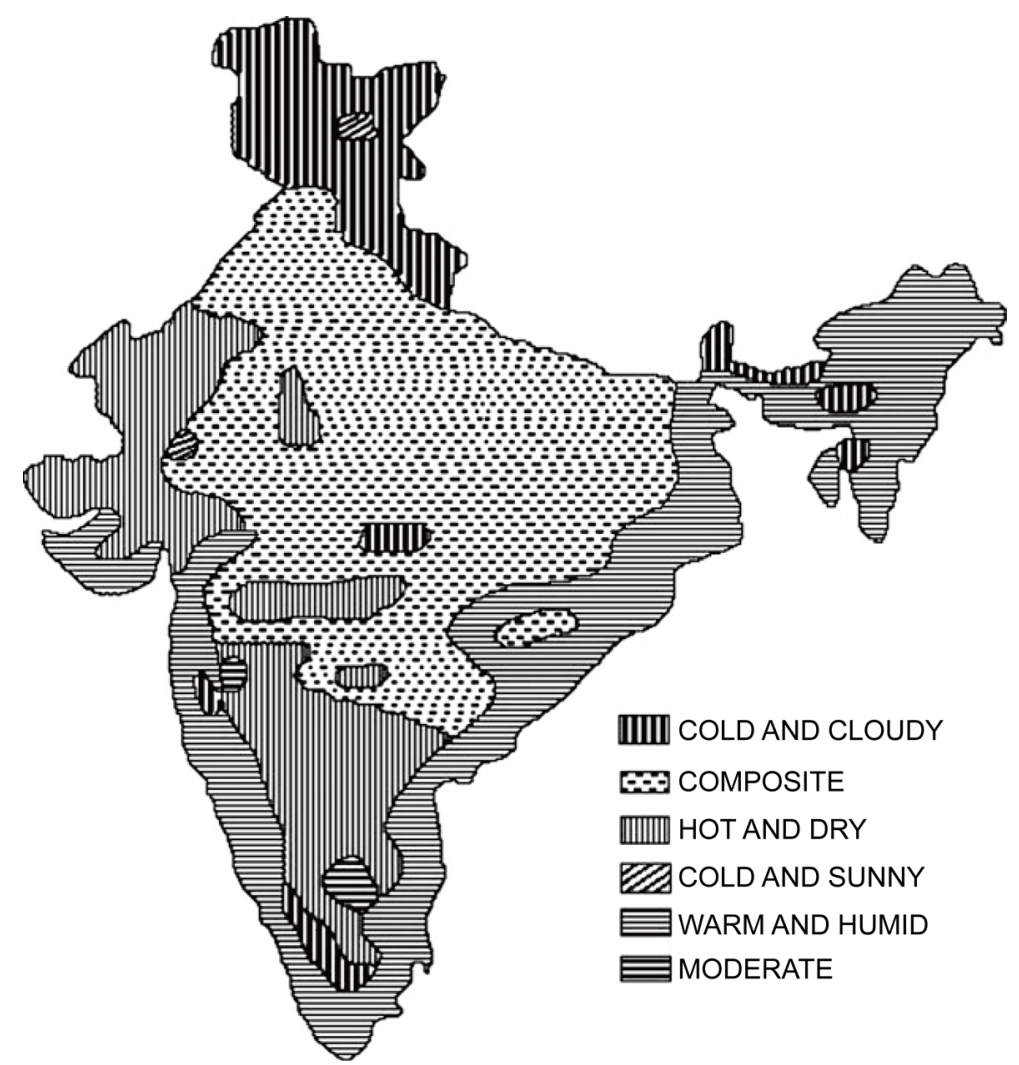

Figure 2. Different climatic regions of India [31]. 

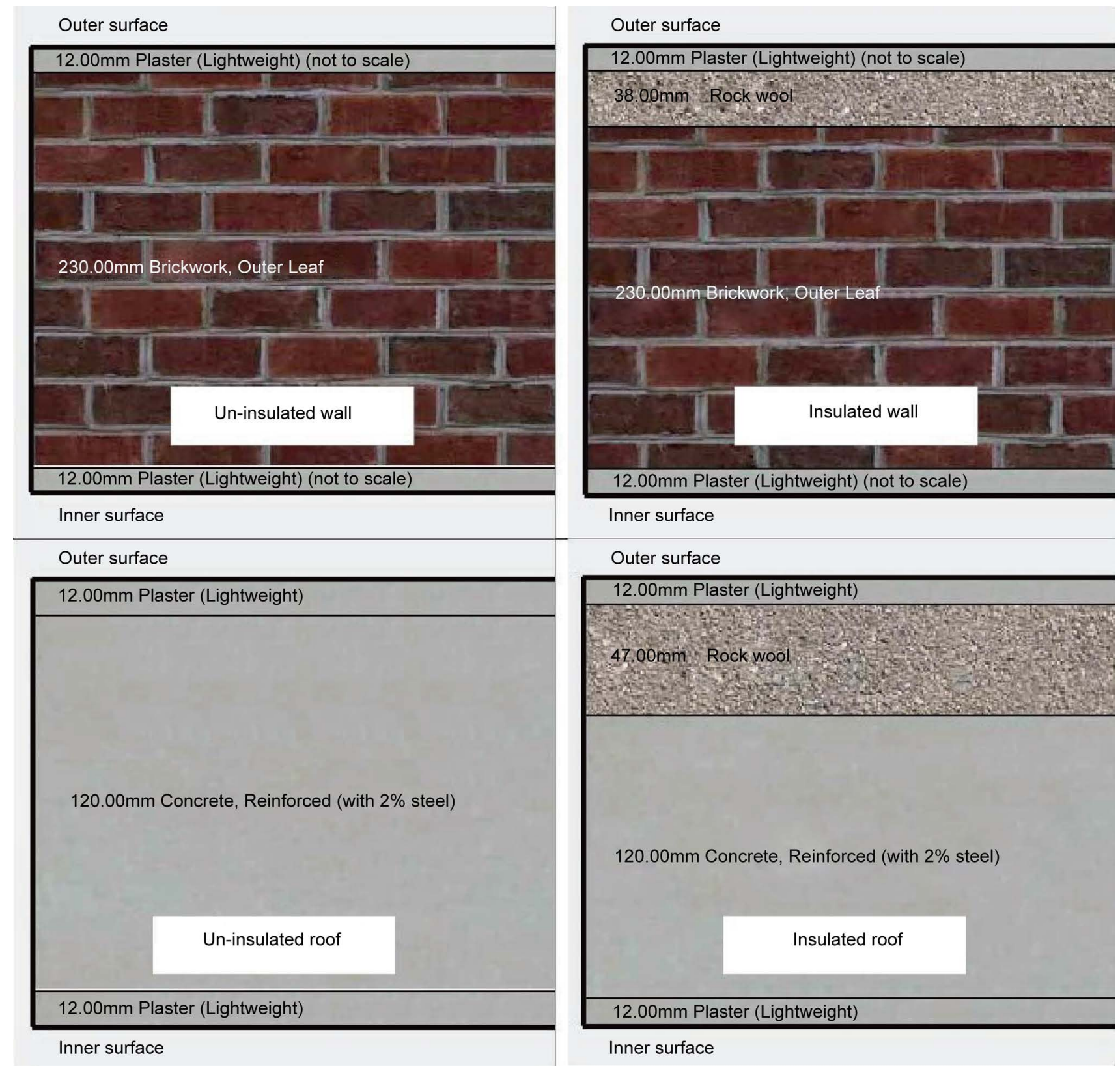

Inner surface

Outer surface

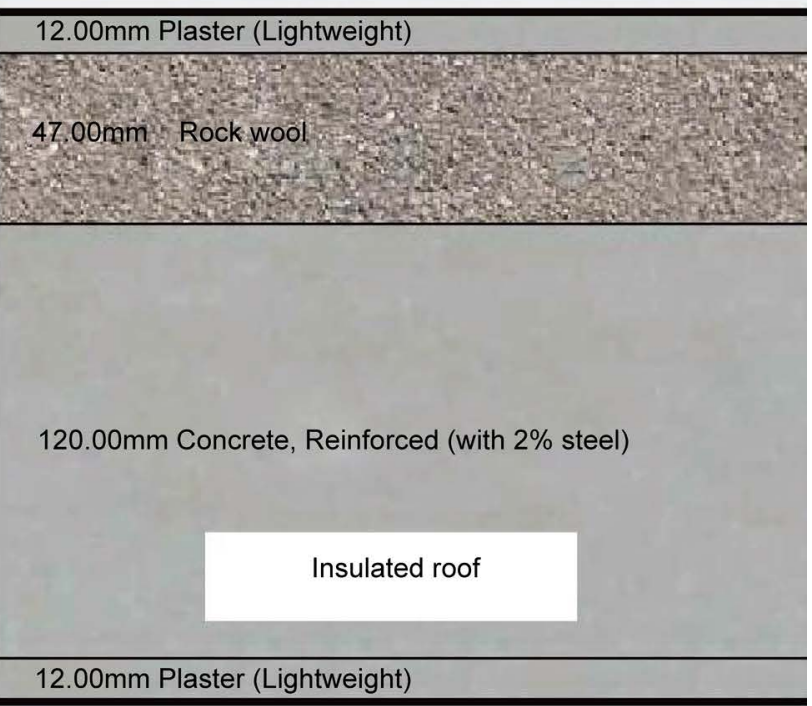

Inner surface

Figure 3. Cross sectional view of insulated and un-insulated wall and roof [35].

Generally, thermal conductivity and cost of insulation material are the two main factors which should be considered for selection of insulation material. Based on the local market survey, expanded polystyrene (EPS), glass wool (GW), and rock wool (RW) are the three most commonly available insulation materials and therefore are chosen for the study. As per the local market survey, cost of insulation is found to be 4600 Indian National Rupees (Rs.) $/ \mathrm{m}^{3}, 5600$ Rs. $/ \mathrm{m}^{3}$ and $3000 \mathrm{Rs} . / \mathrm{m}^{3}$ for EPS, GW and RW respectively. Average electricity cost is considered as $7 \mathrm{Rs} . / \mathrm{kWh}$ with an assumed increase rate $10 \%$ and discount rate of $8 \%$. The cooling system (air-conditioners) coefficient of performance (COP) is assumed as 3.0. The indoor design temperature is considered as $23^{\circ} \mathrm{C}$. 
Table 1. Thermo physical properties of a typical ATM envelope.

\begin{tabular}{|c|c|c|c|c|}
\hline Material & $\begin{array}{l}\text { Convection heat transfer } \\
\text { coefficient }\left(h, W / m^{2} K\right)\end{array}$ & $\begin{array}{l}\text { Thermal conductivity } \\
\qquad(\mathrm{k}, \mathrm{W} / \mathrm{m} \cdot \mathrm{K})\end{array}$ & $\begin{array}{c}\text { Size (m) } \\
(\mathrm{L} \times \mathrm{W} \times \mathrm{H})\end{array}$ & $\begin{array}{l}\text { Thermal resistance } \\
\qquad\left(\mathrm{R}, \mathrm{m}^{2} \mathrm{~K} / \mathrm{W}\right)\end{array}$ \\
\hline External surface & 22.7 & - & - & 0.044 \\
\hline \multicolumn{5}{|c|}{ Insulation types } \\
\hline Expanded polystyrene (EPS) & - & $0.036^{*}$ & - & - \\
\hline Rock wool (RW) & - & $0.042^{*}$ & - & - \\
\hline \multicolumn{5}{|c|}{ Brick/Block types } \\
\hline FCB & - & $0.84^{\#}$ & $0.26 \times 0.075 \times 0.10$ & 0.274 \\
\hline RCC & - & $2.5^{*}$ & $1 \times 1 \times 0.12$ & 0.048 \\
\hline
\end{tabular}

$*[31],{ }^{*}[21]$.

\subsection{Evaluation of Cooling Energy Requirement}

Absorption of solar radiation by building external surface as well as temperature gradient leads to conduction heat transfer from exterior surface to interior surface. At the same time, convective heat transmission occurs between ambient air and the building exterior surfaces, also between the interior surface and indoor air of the building. Building annual energy consumption can be estimated by using degree-hours method under static conditions. By using hourly weather data, the number of cooling degree hours annually is calculated as [32]:

$$
C D H=(1 \text { year }) \sum_{1}^{365}(1 \text { day }) \sum_{1}^{24}\left|T_{s a}-T_{i a}\right|
$$

where, $C D H$ is the annual cooling degree hours ( ${ }^{\circ} \mathrm{C}$-hours), $T_{s a}$ is outside sol air temperature $\left({ }^{\circ} \mathrm{C}\right)$ and $T_{i a}$ is indoor design air temperature (IDT) $\left({ }^{\circ} \mathrm{C}\right)$.

Hourly temperature profile for whole year is generated using e Quest v.3.6 software based on DoE-2 [33] with international weather for energy calculation (IWEC) data as an input for the four selected climatic zones. $C D H$ of the selected four climates are shown in Table 3. Total annual energy consumption of cooling system per unit area of building envelope $\left(E_{\circ} \mathrm{kWh}\right)$ can be calculated as [32]:

$$
E_{C}=\frac{U * C D H}{C O P}
$$

where, $U$ is the envelope overall heat transfer coefficient $\left(\mathrm{W} / \mathrm{m}^{2} \cdot \mathrm{K}\right)$ and $C O P$ is coefficient of performance of cooling system. The difference between the overall heat transfer coefficients of un-insulated and insulated building structure is expressed as:

$$
\Delta U=\frac{1}{R_{s}}-\frac{1}{R_{s}+R_{\text {ins }}}=\frac{1}{\frac{1}{h_{i}}+\frac{x_{1}}{k_{1}}+\frac{x_{2}}{k_{2}}+\cdots \frac{x_{n}}{k_{n}}+\frac{1}{h_{e}}}-\frac{1}{\frac{1}{h_{i}}+\frac{x_{1}}{k_{1}}+\frac{x_{2}}{k_{2}}+\cdots \frac{x_{n}}{k_{n}}+\frac{1}{h_{e}}+\frac{x}{k_{i n s}}}
$$


where, $R_{s}$ is the building structure resistance (either wall or roof) and $\mathrm{h}_{\mathrm{i}}$ and $\mathrm{h}_{\mathrm{e}}$ are convection heat transfer coefficient for interior and exterior surface of cooled space, respectively. $k_{1}, k_{2}, \cdots, k_{n}$, are thermal conductivity of different layers of wall, and $x_{1}, x_{2}, \cdots$, $x_{n}$, are their thicknesses respectively. $R_{i n s}$ is the insulation thermal resistance, $x$ is the insulation thickness $(\mathrm{m})$ and $k_{\text {ins }}$ is the thermal conductivity of insulation material $(\mathrm{W} / \mathrm{mK})$.

\subsection{Economic Analysis and Optimum Insulation Thickness}

$P_{1}-P_{2}$ method is utilised for calculating life-cycle cost [34]. Here, $P_{1}$ is a multiplier that establishes the present value of future energy costs. It depends upon discount rate $d$, electricity cost inflation rate $i$, and life time period $N$ of the insulation (assumed as 10 years). The value of $P_{1}$ can be estimated as:

$$
P_{1}(i, d, N)=\sum_{j=1}^{N} \frac{(1+i)^{j-1}}{(1+d)^{j}}=\left\{\begin{array}{l}
\frac{1}{(d-i)}\left[1-\left(\frac{1+i}{1+d}\right)^{N}\right], i \neq d \\
\frac{N}{1+i}, i=d
\end{array}\right.
$$

$P_{2}$ is the ratio of life cycle expenditures incurred owing to the additional capital investment to the preliminary investment. Elevated value of $P_{2}$ designates that the system has a low initial investment but having higher costs incurred over its life time period. It is defining as [34]:

$$
P_{2}=1+P_{1} M_{s}-\frac{R_{v}}{(1+d)^{N}}
$$

where, $M_{s}$ is the ratio of the annual maintenance/repair cost to the original first cost, $R_{V}$ is the ratio of the resale value to the first cost. In this study, $P_{2}$ can be taken as 1 if the maintenance/repair cost and resale value is assumed to be zero. LCC of the insulation material and the energy consumption can be estimated as:

$$
L C C=P_{1} C_{e} E_{c}+P_{2} C_{i} x
$$

where, $C_{e}$ is the cost of electricity (Rs./kWh) and $C_{i}$ is the cost of insulation material per unit volume $\left(\mathrm{Rs} . / \mathrm{m}^{3}\right)$. Savings over life cycle (LCS) is the divergence between the preserved energy cost and the cost of insulation, and can be expressed as;

$$
L C S=P_{1} C_{e} \Delta E_{c}-P_{2} C_{i} x
$$

where, $\Delta E_{c}$ is the difference of annual energy consumption of cooling system of uninsulated and insulated envelope. The OIT, expressed as $x_{o p t}$, is obtained by minimising LCC or by maximising LCS as follows:

$$
x_{\text {opt }}=\sqrt{\frac{C_{e} k_{\text {ins }} C D H}{P_{2} C_{i} C O P}}-R_{s} k_{i n s}
$$

By setting Equation (7) equal to zero, the payback period of insulation cost $N_{p}$, is expressed as: 


$$
\begin{aligned}
& N_{p}=\frac{\ln \left\{1-\frac{P_{2} C_{i}(d-i)\left(R_{s} x+k_{\text {ins }} R_{s}^{2}\right) C O P}{C_{e} C D H}\right\}}{\ln \left(\frac{1+i}{1+d}\right)}, i \neq d \\
& N_{p}=\left\{\frac{P_{2} C_{i}(1+i)\left(R_{s} x+k_{\text {ins }} R_{s}^{2}\right) C O P}{C_{e} C D H}\right\}, i=d
\end{aligned}
$$

\subsection{Proposal for Rooftop Solar PV System}

To meet the lighting and other auxiliary load demand of the ATM, grid connected roof top solar PV system is proposed. Annual electricity consumption of a typical ATM located in India is found to be $2.4 \mathrm{MWh}$ on an average through energy simulation by DesignBuilder software [35]. Design Builder results are used by RETScreen simulation software [36] for sizing of rooftop solar PV system to meet the annual miscellaneous energy demand (except air-conditioning) for the ATMs. RETScreen is clean energy management software to determine the economic feasibility of the proposed solar energy system along with its environmental impact.

Solar radiation and ambient temperature for the four different climatic zones are obtained from RETScreen international database based on ground monitoring station and NASA's global satellite database [36]. The installation cost of the proposed rooftop solar PV system is estimated as Rs. 191880 [37]. Technical specifications of roof top solar PV system as well as the data (installation costs and financial parameters) required for the economic analysis are depicted in Table 2. The SPV panel is tilted at an angle of local latitude with the horizontal and facing south for collecting maximum solar insolation throughout the year.

In India, around 65\% [38] of power generation is from fossil fuel based thermal power plants. The average intensity of GHG emissions from grid electricity in India is considered as $1.186 \mathrm{tCO}_{2} / \mathrm{MWh}$ [36] for all fuel types and transmission and distribution losses are taken as $23.04 \%$ [39]. Hence, the GHG emission reduction (tonnes/year) through insulation is calculated as follows:

Table 2. Technical specification of PV panel [37].

\begin{tabular}{cccc}
\hline Variables & Specification & Variables & Specification \\
\hline Manufacturer & Trina Solar & Solar collector Nos. & 8 \\
PV module type & Mono-Si & PV tracking mode & fixed \\
Module number & TSM-195DC/DA01A & Inverter capacity & $1.5 \mathrm{~kW}$ \\
Solar PV panel capacity $(\mathrm{W})$ & 195 & Solar collector area $\left(\mathrm{m}^{2}\right)$ & 10 \\
Frame area $\left(\mathrm{m}^{2}\right)$ & 1.28 & Installation cost $(\mathrm{Rs} . / \mathrm{kW})$ & 123000 \\
Efficiency $(\%)$ & 15.3 & Life (years) & 20 \\
System Capacity $(\mathrm{kW})$ & 1.5 & & \\
\hline
\end{tabular}




$$
\mathrm{CO}_{2} \text { emissions mitigated }=1.186 \times \Delta E_{c}(\mathrm{MWh} / \text { year })
$$

The additional $\mathrm{CO}_{2}$ emission reduction by using solar PV systems has also been evaluated as in the case of insulation.

\section{Results and Discussion}

Using the methodology outlined above, various parameters i.e. OIT, LCS and payback $(\mathrm{Pb})$ period for three different insulation materials (EPS, GW \& RW) have been evaluated for four different climatic zones of India, where cooling is required. Further these optimum insulation thicknesses are used to determine the energy saving potential of isolated bank ATM's throughout the country.

Figure 4 demonstrate the variation of the annual fuel consumption cost and cost of insulation against wall insulation thickness of EPS insulation material for hot and humid climate at $23^{\circ} \mathrm{C}$ indoor design temperature. It has been noted that increasing the insulation thickness will bring about a continual reduction in fuel cost and in addition straight increment in insulation cost. Whole of fuel cost and expense of included insulation material will render life cycle cost. The insulation thickness value at minimum life cycle cost is taken as the optimum insulation thickness (OIT).

Table 3 depicts the values of OIT, LCS and $\mathrm{Pb}$ of wall and roof for the selected climatic zones at $23^{\circ} \mathrm{C}$ indoor design temperature. For a given insulation material, increase in $\mathrm{CDH}$ results in increase in OIT as it is directly proportional to half order power of $\mathrm{CDH}$. LCS will also follow the same trend with $\mathrm{CDH}$. Insulation having maximum LCS will result in minimum payback period.

Out of the three insulation material analysed, RW insulation holds the maximum OIT values and minimum payback period while GW insulation has minimum OIT and maximum payback period. EPS insulation falls in between. With reference to Equation (8), it is observed that the OIT is directly proportional to the square root of thermal conductivity of insulation and inversely proportional to the square root of insulation cost. Further, as the thermal resistance of roof structure is lower than the wall structure, therefore OIT for roof is found more than wall structure.

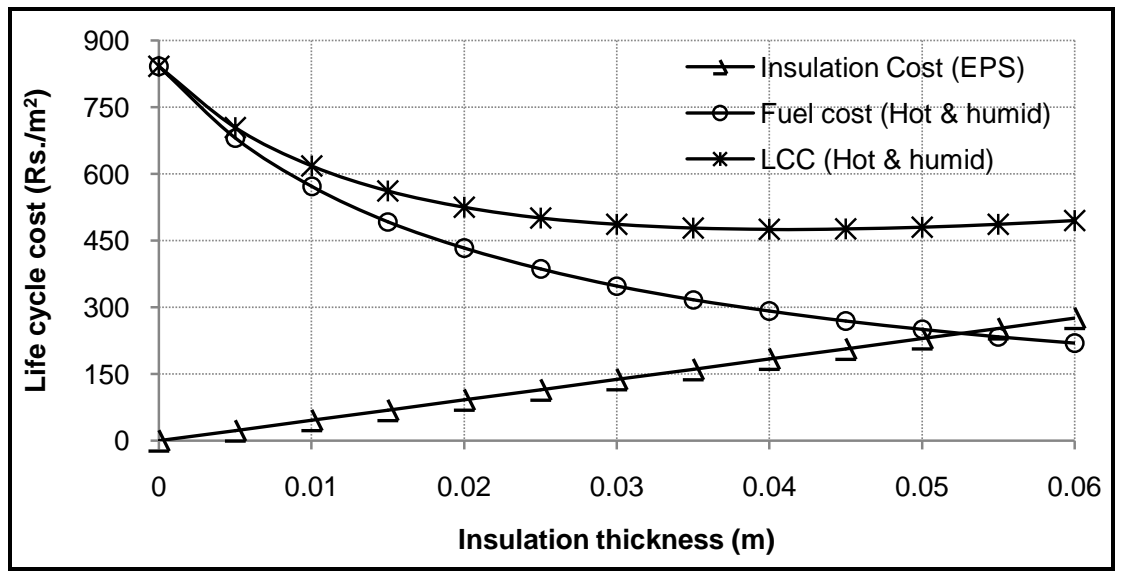

Figure 4. Variation of LCC with insulation thickness of EPS in hot and humid zone. 
As per the Reserve Bank of India estimates, the total number of ATMs spread throughout the country is 189189 [40]. Generally an ATM comprises cash dispensing machine placed in a $3 \times 3 \times 3.5 \mathrm{~m}$ air conditioned room. ATMs provide $24 \times 7$ services as well as operate at low temperature ranges of cooling, hence have high energy bill. Insulating the ATM's envelope is not a popular technique in India. Therefore the potential of total energy savings by insulating ATMs has been evaluated on a national basis. Figure 5 shows an ATM and its simulation model. A dynamic energy simulation tool DesignBuilder [35] is used for the energy simulation. It has a comprehensive user interface for EnergyPlus dynamic thermal simulation engine and generates building annual energy performance data utilising hourly weather files of ISHRAE.

Table 4 depicts the values of cooling energy consumption of un-insulated and insulated ATMs along with their annual savings. Among the three investigated insulation materials the maximum energy reduction and savings are obtained for RW insulation. Out of the four climatic zones, three of them have almost same energy saving potential while moderate zone falls on a relatively lower side. Annual economic benefits are found maximum for RW insulation while GW has minimum and EPS falls in between. Assuming uniform distribution of ATM's through the four climate zones of the country, the total life cycle savings would be of the order of approximately Rs. 8600 million

Table 3. $\mathrm{CDH}$, OIT, LCS and $\mathrm{Pb}$ for insulation materials in different climates.

\begin{tabular}{|c|c|c|c|c|c|c|c|c|c|c|c|c|c|}
\hline \multicolumn{2}{|c|}{ Climate } & \multicolumn{3}{|c|}{ Moderate } & \multicolumn{3}{|c|}{ Composite } & \multicolumn{3}{|c|}{ Hot \& Dry } & \multicolumn{3}{|c|}{ Hot \& Humid } \\
\hline Insulation & & EPS & GW & RW & EPS & GW & RW & EPS & GW & RW & EPS & GW & RW \\
\hline \multirow{2}{*}{ OIT (m) } & wall & 0.025 & 0.021 & 0.038 & 0.036 & 0.031 & 0.052 & 0.037 & 0.032 & 0.053 & 0.043 & 0.037 & 0.060 \\
\hline & roof & 0.034 & 0.029 & 0.047 & 0.044 & 0.039 & 0.061 & 0.045 & 0.041 & 0.063 & 0.051 & 0.046 & 0.069 \\
\hline LCS $\left(\mathrm{Rs} . / \mathrm{m}^{2}\right)$ & roof & 397 & 357 & 437 & 680 & 627 & 733 & 724 & 669 & 778 & 902 & 841 & 963 \\
\hline \multirow{2}{*}{$\mathrm{Pb}$ (years) } & wall & 4.3 & 4.9 & 3.7 & 3.5 & 3.9 & 3.0 & 3.4 & 3.8 & 2.9 & 3.1 & 3.5 & 2.7 \\
\hline & roof & 2.6 & 3.0 & 2.3 & 2.1 & 2.4 & 1.9 & 2.1 & 2.4 & 1.8 & 1.9 & 2.2 & 1.7 \\
\hline
\end{tabular}
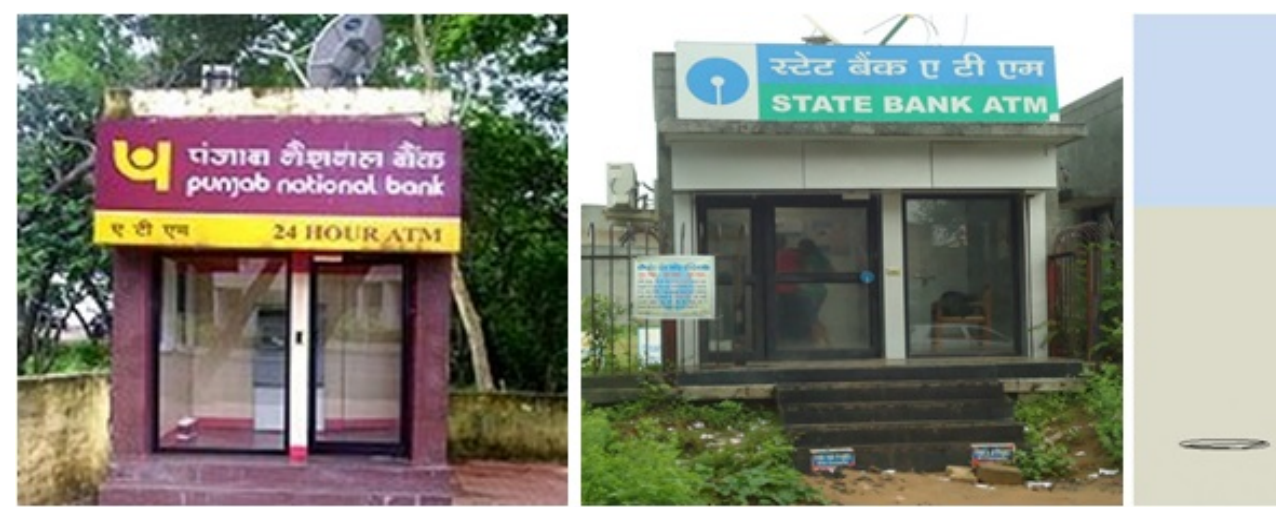

Figure 5. Some real ATM snaps and the simulated model. 
over the 10 year lifespan of insulation material. Carbon reduction potential for the three insulation materials is also estimated and is shown in Table 4. It is found that average carbon emission mitigation of 1.4 million $\mathrm{tCO}_{2}$ is possible from insulating the ATMs across the country in ten years.

From RETScreen simulations it is observed that the on-site energy generated by rooftop PV system will fulfil the ATM energy demand (except air conditioning) for all the climatic zones. The annual power generation by the proposed SPV system is depicted in Table 5. The surplus energy generated by the renewable system can be transferred to the national grid which will provide some addition economic benefits. The annual power generation through the rooftop solar PV system ranges from 2.4 to 2.8 MWh depending upon climatic zones. Maximum power generation is obtained for hot \& dry zone while hot and humid climate zone have the minimum power generation.

Results show that the payback period for the proposed SPV system varies from 7.0 to 7.5 years depending on the climatic zone. It is observed that hot and dry climate provides the lowest payback period and maximum annual saving, while hot and humid regions have the maximum payback and lowest annual savings. Altogether in the four selected climate zones, average life cycle savings due to rooftop solar PV installation is approximately Rs. 54200 million in a period of 20 years. Further, on a national basis, total carbon reduction potential is nearly 9.2 million $\mathrm{tCO}_{2}$ over a 20 year time period.

\section{Conclusions}

The results indicate that OIT and LCS largely depend on the type of insulation, indoor design temperature, and outside climatic conditions. It is observed that OIT ranges

Table 4. Cooling energy consumptions, annual savings and carbon mitigations from an insulated ATM.

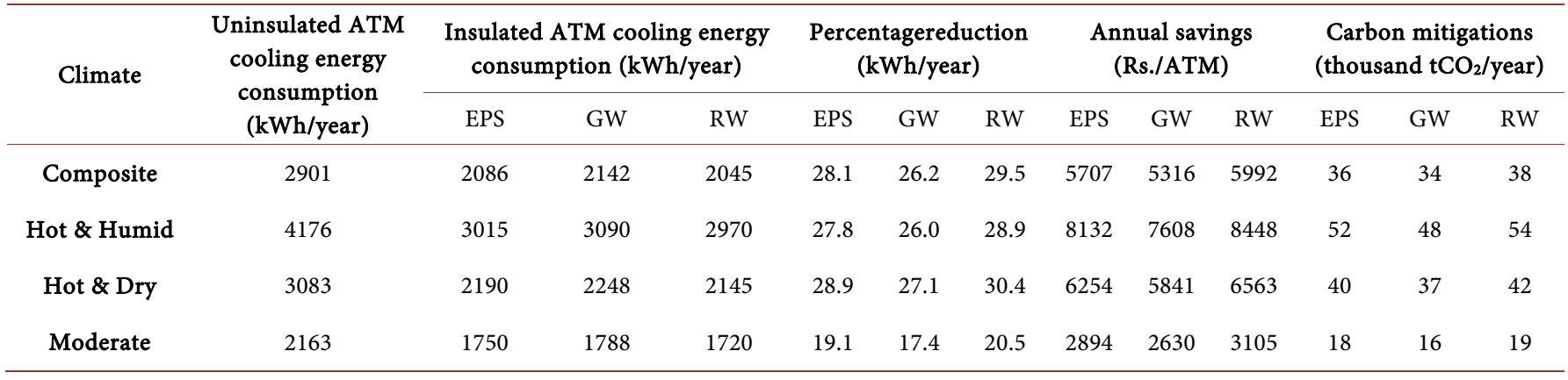

Table 5. Economic and carbon reduction benefits by installing SPV system on a typical ATM.

\begin{tabular}{ccccc}
\hline Climate & $\begin{array}{c}\text { Annual Power generation } \\
\text { (MWh/year) }\end{array}$ & $\begin{array}{c}\text { Annual savings } \\
\text { (Rs./ATM) }\end{array}$ & $\begin{array}{c}\text { Payback period } \\
\text { (years) }\end{array}$ & $\begin{array}{c}\text { Carbon mitigation } \\
(\text { tCO } / \text { year-ATM) }\end{array}$ \\
\hline Composite & 2.469 & 17284 & 7.5 & 2.9 \\
Hot \& humid & 2.433 & 17025 & 7.5 & 2.9 \\
Hot \& dry & 2.786 & 19501 & 7.0 & 3.3 \\
Moderate & 2.574 & 18014 & 7.3 & 3.1 \\
\hline
\end{tabular}


from $0.025 \mathrm{~m}$ to $0.06 \mathrm{~m}$ for external wall and $0.034 \mathrm{~m}$ to $0.069 \mathrm{~m}$ for roof and payback period for optimum insulation thickness ranges from 2.7 to 4.9 years for wall and 1.7 to 3.0 years for roof depending on the insulation material, climatic zone and the indoor design temperature. Payback period for rooftop solar PV system ranges from 7.0 to 7.5 years for different climatic zones. The energy savings range from $17 \%-30 \%$, based on the insulation material and the climatic zone.

From the present study, it is concluded that the selection of an appropriate insulation material with optimum thickness for ATMs is expected to provide significant economic and environmental benefits. These benefits are further increased if solar PV systems are installed to partially meet the ATM electricity requirements. On a national basis, the combined economic benefit of the two systems (insulation and solar PV) is approximately Rs. 3570 million on an annual basis. Further, the total carbon reduction potential is approximately 0.6 million $\mathrm{tCO}_{2}$ on an annual basis. From this study, it is observed that properly insulated ATMs integrated with rooftop solar PV systems in India, can significantly reduce the energy costs as well as carbon emissions. Such an initiative can contribute to reducing the carbon intensity of the Indian economy, and help fulfill its recent commitment to the COP-21 climate change agreement in Paris.

\section{References}

[1] McKinsey \& Company (2009) Environmental and Energy Sustainability: An Approach for India.

http://www.mckinsey.com/client service/sustainability/latest thinking/greenhouse gas ab atement cost curves

[2] Planning Commission (2011) Interim Report of the Expert Group on Low Carbon Strategies for Inclusive Growth.

http://www.moef.nic.in/downloads/public-information/Interim\%20Report\%20of\%20the $\% 20$ Expert\%20Group.pdf

[3] Al-Homoud Mohammad, S. (2005) Performance Characteristics and Practical Applications of Common Building Thermal Insulation Materials. Building and Environment, 40, 353366. http://dx.doi.org/10.1016/j.buildenv.2004.05.013

[4] Mahlia, T.M.I., Taufiq, B.N., Ismail and Masjuki, H.H. (2007) Correlation between Thermal Conductivity and the Thickness of Selected Insulation Materials for Building Wall. Energy and Buildings, 39, 182-187. http://dx.doi.org/10.1016/j.enbuild.2006.06.002

[5] Hasan, A. (1999) Optimizing Insulation Thickness for Buildings Using Life Cycle Cost. Applied Energy, 63, 115-124. http://dx.doi.org/10.1016/S0306-2619(99)00023-9

[6] Satman, A. and Yalcinkaya, N. (1999) Heating and Cooling Degree-Hours for Turkey. Energy, 24, 833-840. http://dx.doi.org/10.1016/S0360-5442(99)00035-3

[7] Sisman, N., Kahya, E., Aras, N. and Aras, H. (2007) Determination of Optimum Insulation Thicknesses of the External Walls and Roof (Ceiling) for Turkey's Different Degree-Day Regions. Energy Policy, 35, 5151-5155. http://dx.doi.org/10.1016/j.enpol.2007.04.037

[8] Ucar, A. and Balo, F. (2009) Effect of Fuel Type on the Optimum Thickness of Selected Insulation Materials for the Four Different Climatic Regions of Turkey. Applied Energy, 86, 730-736. http://dx.doi.org/10.1016/j.apenergy.2008.09.015

[9] Çomakli, K. and Yüksel, B. (2003) Optimum Insulation Thickness of External Walls for Energy Saving. Applied Thermal Engineering, 23, 473-479. 
http://dx.doi.org/10.1016/S1359-4311(02)00209-0

[10] Aktacir, M.A., Büyükalaca, O. and Yilmaz, T. (2010) A Case Study for Influence of Building Thermal Insulation on Cooling Load and Air-Conditioning System in the Hot and Humid Regions. Applied Energy, 87, 599-607. http://dx.doi.org/10.1016/j.apenergy.2009.05.008

[11] Al-Sanea, S.A. and Zedan, M.F. (2002) Optimum Insulation Thickness for Building Walls in a Hot-Dry Climate. International Journal of Ambient Energy, 23, 115-126. http://dx.doi.org/10.1080/01430750.2002.9674880

[12] Daouas, N. (2011) A Study on Optimum Insulation Thickness in Walls and Energy Savings in Tunisian Buildings Based on Analytical Calculation of Cooling and Heating Transmission Loads. Applied Energy, 88, 156-164. http://dx.doi.org/10.1016/j.apenergy.2010.07.030

[13] Yu, J., Yang, C., Tian, L. and Liao, D. (2009) A Study on Optimum Insulation Thicknesses of External Walls in Hot Summer and Cold Winter Zone of China. Applied Energy, 86, 2520-2529. http://dx.doi.org/10.1016/j.apenergy.2009.03.010

[14] Dombayci, Ö. A., Gölcü, M., \& Pancar, Y. (2006) Optimization of insulation thickness for external walls using different energy-sources. Applied Energy, 83(9), 921-928. http://dx.doi.org/10.1016/j.apenergy.2005.10.006

[15] Dombayci, Ö.Ä. (2007) The Environmental Impact of Optimum Insulation Thickness for External Walls of Buildings. Building and Environment, 42, 3855-3859. http://dx.doi.org/10.1016/j.buildenv.2006.10.054

[16] Bolattürk, A. (2006) Determination of Optimum Insulation Thickness for Building Walls with Respect to Various Fuels and Climate Zones in Turkey. Applied Thermal Engineering, 26, 1301-1309. http://dx.doi.org/10.1016/j.applthermaleng.2005.10.019

[17] Bolattürk, A. (2008) Optimum Insulation Thicknesses for Building Walls with Respect to Cooling and Heating Degree-Hours in the Warmest Zone of Turkey. Building and Environment, 43, 1055-1064. http://dx.doi.org/10.1016/j.buildenv.2007.02.014

[18] Kaynakli, O. (2008) A Study on Residential Heating Energy Requirement and Optimum Insulation Thickness. Renewable Energy, 33, 1164-1172.

http://dx.doi.org/10.1016/j.renene.2007.07.001

[19] Ozel, M. (2011) Effect of Wall Orientation on the Optimum Insulation Thickness by Using a Dynamic Method. Applied Energy, 88, 2429-2435. http://dx.doi.org/10.1016/j.apenergy.2011.01.049

[20] Ozel, M. (2011) Thermal Performance and Optimum Insulation Thickness of Building Walls with Different Structure Materials. Applied Thermal Engineering, 31, 3854-3863. http://dx.doi.org/10.1016/j.applthermaleng.2011.07.033

[21] Ozel, M. (2012) Cost Analysis for Optimum Thicknesses and Environmental Impacts of Different Insulation Materials. Energy and Buildings, 49, 552-559.

http://dx.doi.org/10.1016/j.enbuild.2012.03.002

[22] Ozel, M. and Pihtili, K. (2007) Optimum Location and Distribution of Insulation Layers on Building Walls with Various Orientations. Building and Environment, 42, 3051-3059. http://dx.doi.org/10.1016/j.buildenv.2006.07.025

[23] Wan, K.K.W., Li, D.H.W., Pan, W. and Lam, J.C. (2012) Impact of Climate Change on Building Energy Use in Different Climate Zones and Mitigation and Adaptation Implications. Applied Energy, 97, 274-282. http://dx.doi.org/10.1016/j.apenergy.2011.11.048

[24] Pan, D., Chan, M., Deng, S. and Lin, Z. (2012) The Effects of External Wall Insulation Thickness on Annual Cooling and Heating Energy Uses under Different Climates. Applied Energy, 97, 313-318. http://dx.doi.org/10.1016/j.apenergy.2011.12.009

[25] Tettey, U.Y.A., Dodoo, A. and Gustavsson, L. (2014) Effects of Different Insulation Mate- 
rials on Primary Energy and $\mathrm{CO}_{2}$ Emission of a Multi-Storey Residential Building. Energy and Buildings, 82, 369-377. http://dx.doi.org/10.1016/j.enbuild.2014.07.009

[26] Al-Sanea, S.A. and Zedan, M.F. (2011) Improving Thermal Performance of Building Walls by Optimizing Insulation Layer Distribution and Thickness for Same Thermal Mass. $A p$ plied Energy, 88, 3113-3124. http://dx.doi.org/10.1016/j.apenergy.2011.02.036

[27] Al-Sanea, S.A. (2002) Thermal Performance of Building Roof Elements. Building and Environment, 37, 665-675. http://dx.doi.org/10.1016/S0360-1323(01)00077-4

[28] Al-Sanea, S.A. and Zedan, M.F. (2001) Effect of Insulation Location on Thermal Performance of Building Walls under Steady Periodic Conditions. International Journal of Ambient Energy, 22, 59-72. http://dx.doi.org/10.1080/01430750.2001.9675389

[29] Al-Khawaja, M.J. (2004) Determination and Selecting the Optimum Thickness of Insulation for Buildings in Hot Countries by Accounting for Solar Radiation. Applied Thermal Engineering, 24, 2601-2610. http://dx.doi.org/10.1016/j.applthermaleng.2004.03.019

[30] Ramesh, T., Prakash, R. and Shukla, K.K. (2010) Life Cycle Energy Analysis of Buildings: An Overview. Energy and Buildings, 42, 1592-1600. http://dx.doi.org/10.1016/j.enbuild.2010.05.007

[31] Ramesh, T., Prakash, R. and Shukla, K.K. (2012) Life Cycle Energy Analysis of a Residential Building with Different Envelopes and Climates in Indian Context. Applied Energy, 89, 193-202. http://dx.doi.org/10.1016/j.apenergy.2011.05.054

[32] Kayfeci, M., Keçebaş, A. and Gedik, E. (2013) Determination of Optimum Insulation Thickness of External Walls with Two Different Methods in Cooling Applications. Applied Thermal Engineering, 50, 217-224. http://dx.doi.org/10.1016/j.applthermaleng.2012.06.031

[33] York, D. and Cappiello, C. (1981) DOE-2 Engineer's Manual: Version 2.1 A. CA: Energy and Environmental Division, Lawrence Berkeley Laboratory, LBL-8706 Rev. 2, LA-7689-M (Rev. 2).

[34] Duffie, J.A. and Beckman, W.A. (1980) Solar Engineering of Thermal Processes. John Wiley and Sons, New York, 398-402.

[35] DesignBuilder (2010). http://www.designbuilder.co.uk/

[36] RETScreen International (2015). http://www.nrcan.gc.ca/energy/software-tools/7465

[37] Trina Solar (2015). http://www.solarelectricsupply.com/residential-solar-system-cost

[38] (2012) India Energy Book. World Energy Council. http://www.indiaenvironmentportal.org.in/files/file/ieb2012.pdf

[39] Load Generation Balance Report 2014-15. Ministry of Central Electricity Authority, New Delhi, Government of India. http://cea.nic.in/reports/annual/lgbr/lgbr-2014.pdf

[40] Reserve Bank of India (2015). https://www.rbi.org.in/scripts/ATMView.aspx 
Submit or recommend next manuscript to SCIRP and we will provide best service for you:

Accepting pre-submission inquiries through Email, Facebook, LinkedIn, Twitter, etc. A wide selection of journals (inclusive of 9 subjects, more than 200 journals)

Providing 24-hour high-quality service

User-friendly online submission system

Fair and swift peer-review system

Efficient typesetting and proofreading procedure

Display of the result of downloads and visits, as well as the number of cited articles

Maximum dissemination of your research work

Submit your manuscript at: http://papersubmission.scirp.org/

Or contact ojee@scirp.org 